\title{
The Quranic Issues And Injunctions About Dowry Money
}

\author{
Muhammad Shakil Auj \\ Faculty of Islamic Studies \\ University of Karachi
}

\begin{abstract}
Dower is a gift presented to the bride from bridegroom at the time of marriage. This is a token from a husband to his wife which shows that he will continue his services and gifts to his wife in future also. Moreover, he will also be responsible for her needs of food and cloth. Some people, who say that dower is a return of something or service, it is wrong, because dower is not a cost of women but it is for the increase of social status of a women. In Pakistani societies payment of dower is very rare. Commonly it is considered as a tradition to write only. At the time of marriage ceremony it is usually not paid, but it is considered obligatory and compulsory at the time of separation by means of divorce. This misunderstanding is occurred due to the ignorance of the Holy Quran. In the following article all the problems related to dower are explained comprehensively in the light of Holy Quran.
\end{abstract}

$$
\begin{aligned}
& \text { تلخيصِ مقال }
\end{aligned}
$$

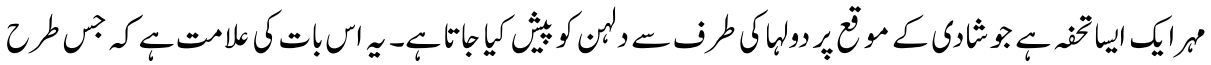

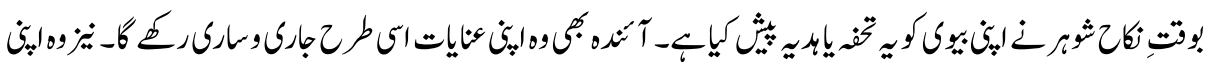

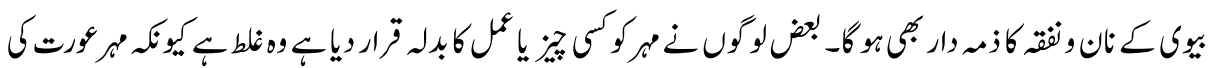

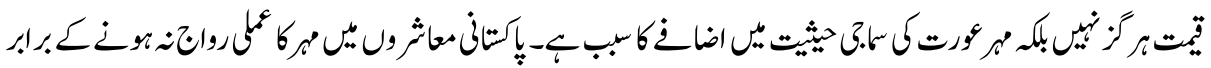

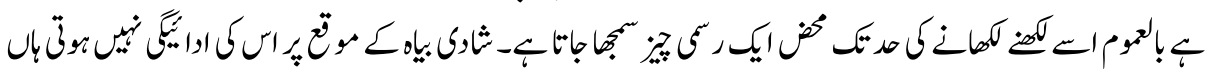

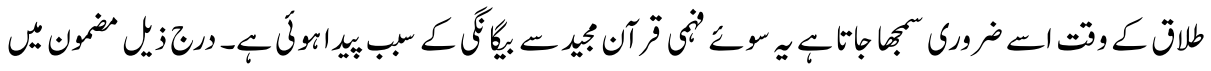

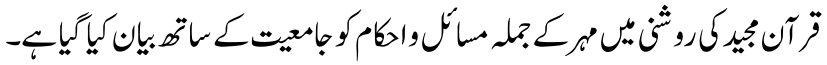

It is very important for Nikah to pay the dowry money but it is not regarded as the condition for establishing Nikah. Therefore those who say that nikah is not possible without dowry money are not right (The Quranic argument will be given a little later on the following pages)

The Quran has used following four words for that which we call Meher (dowry Money) in our language and terminology:
1. Provision
2. Charity money
3. Reward
4. Obligation

It should be clear that dowry money is not a fixed amount with which woman is bought. This is just a gift which is given with one's own will and consent, but it is necessary to be given. 
Now consider the Quranic words and the places on which they are used regarding Meher:-

First of all see the place where the meaning of 'Meher' is given by the word 'Provision'.

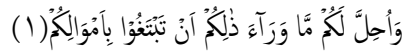

"And except them (all women) are legitimate for you (in a way that ) you want to marry (them ) with your provisions."

This giving of provision is technically called 'Meher'. The word 'Sadqa' (Charity money) is also used for Meher. The Quran says:

"And pay the women their Meher without any return."

The word 'Nahla' has been used in the verse. According to Imam Raghib Isphahani:

'Nahla is something which is given as gift', and in Tafseer e Baidawi:

'Nahla is something which is given with full will and consent without a hope of any return.'

Now consider the use of the word 'Ajr' (Reward) for Meher:

Meher is not the right of only free women but maids also have a right of having meher. In order to mention this fact, it has been said:

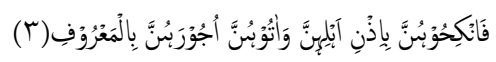

"Hence marry them (the maids) by the permission of their owners and give their meher according to the custom."

For Muslim women and the pious women of the people of the scripture, it is said:

"When you give them their dowry money"

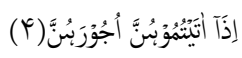

Prophet Muhammad (Allah's peace and blessing be upon him) was also restricted to pay the dowry money. In this way paying the dowry money is a sunnah of Hazrat Mohammad also.

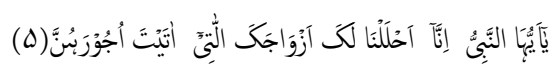

“O' Prophet! We have made those of your wives lawful for you whom you have paid their dowry money."

For the migrated believer women who came to the aboard of faith ( daruleman) from the aboard of disbelief ( darulkufr), it is said:

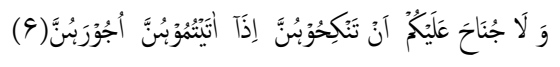


"And there is no sin upon you that you marry them, when you pay them their dowry money."

Since paying the dowry money is according to the commands of God, hence the word 'Obligation' is also used for it.

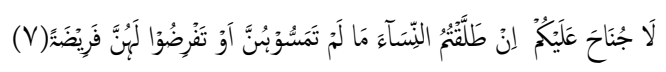

"There is no sin upon you if you divorce the women, while you have not touched them or determined the dowry money."

To make an act 'Wajib' (necessary) upon a thing is called 'Farz' (obligation) like it is said in surah Al-Noor:

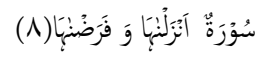

Here 'Fardnahaa'(فَ) means we have made this act 'Wajib' for you. Same is the meaning of 'Fard' in:

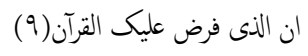

“That is the Being who has made this act 'Wajib' (necessary) for you to act upon the Quran."

Hence this fact is clarified that in the verse 'Farida' is meant for dowry money and 'Tafredu' is meant for the determination of its amount .

This should be understood clearly that since dowry money is a gift from the husband to the wife.Therefore it is actually an expression of the fact that today he (i.e the husband) is giving his life partner a gift item or gift money (i.eMeher) and he will give it in future also, and this kindness and love will always continue for the life time. Obviously, the quantity or amount of dowry money could not be fixed. But since it is necessary to give dowry money therefore, it should be according to the status of the husband and this status could be of giving 'a hump of gold' like the Quran says:

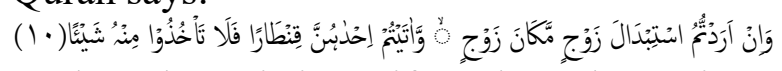

"And if you want (to marry) another wife to replace the Existing wife and you have given a hump of gold to her (even then) do not take any thing from it back."

This verse explains that dower must be according to the person's financial status. Fixing dowry money, which could not be paid, is absolutely against the Quran. No doubt the word 'Qintaar' is given in the verse which is used for an infinite quantity, but the word 'Aataitum' has made its meanings as something which could be paid. It means that if a man determines millions of rupees as dowry money of his wife then he cannot be stopped doing that, but only if he can pay that.

Prophet Muhammad (Allah's peace and blessing be upon him) has said: 
"The best Nikkah is one (according to the dowry money) which is the easiest one." According to a hadith, that woman is regarded as the best whose dowry money is easy for her husband to pay.

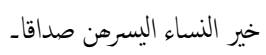

Another hadith said:

"That woman brings the blessings the most, whose dowry money is easy."

$$
\text { اعظم النساء برك: اليسر من صداقا- }
$$

Besides, this is also something which should be memorized by every Muslim that dowry money should be paid along with Nikah ...., but ..... Nikah could be happened without fixing the dowry money. Consider the Quranic argument in this regard:

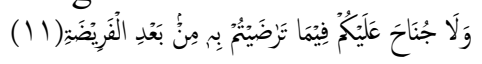

"You are not answerable if you divorce your wives while you have not yet touched them or determined their dowry money."

It should be clear that in case dowry money is not determined then it should be determined on similar dowry money i.e. it should be seen that how much Meher was given by people of the same status in the family, then the same dowry money will be determined for that woman also.

Similarly another thing which every Muslim should know is that if the dowry money has not been paid at the time of Nikah then it could be made lesser or more with the consent of the husband and wife, like we have learned:

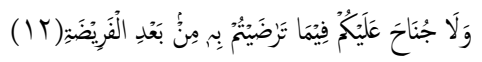

"And there is no sin upon you that after determining the dowry money you will mutually agree (upon making it more or less)."

The agreement which is mentioned in the verse is about making the dowry money more or less which we have made clear in the translation.

After Nikah if divorce happens before intercourse / being alone (Khalwat) then ... if the dowry money was not determined then the husband must have to give something according to his status.

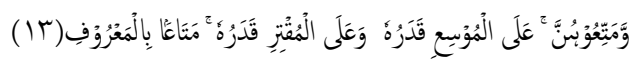

"The well off according to his richness and the poor according to his means must necessarily give some provision according to the custom."

If the dowry money was determined then half of it must be given.

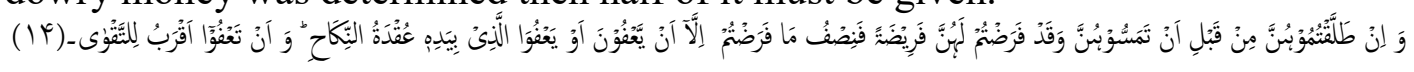


"And if you divorce them before you touched them and you have determined the dowry money then give the half of what is determined, except if they (the wives) forgive it or the person in whose hand is the (power of untying ) the knot of which forgives (his right). (And O' men! if) you forgive then it is very nearer to piety.'

According to the verse the women has a freedom that if she wants to leave her right then she can leave the whole of dowry money. However, the appreciateable act is that the man should give her the whole of dowry money instead of half, but at least half will be given in any case.

\section{References}

Al-Nisa/24

$\mathrm{Ibid} / 4$

$\mathrm{Ibid} / 25$

Al-Maidah/5

Al-Ahzab/50

Al-Mumtahina/10

Al-Baqara/236

Al-Noor/1

Al-Qasas/85

Al-Nisa/20

Al-Baqara/236

Al-Nisa/24

Al-Baqara/236

Prof. Dr. Muhammad Shakil Auj is Dean, Faculty of Islamic Studies, University of Karachi. 